\title{
À procura de si mesmo no turbilhão da Guerra Civil Espanhola (1936-1939), em Saga, de Erico Verissimo
}

\author{
Searching himself in the whirl od the Spanish Civil War (1936-1939) \\ in Saga, by Erico Verissimo
}

\author{
DENISE ROCHA \\ Universidade da Integração Internacional da Lusofonia Afro-Brasileira - Redenção - Ceará - Brasil
}

a

\begin{abstract}
Resumo: Baseado em relatos verídicos, narrados por dois participantes da Guerra Civil Espanhola (1936-1939), Erico Verissimo escreveu o romance Saga (1940) sobre a trajetória ficcional do voluntário brasileiro Vasco Bruno. Sem grandes objetivos de vida, esse jovem entediado participa de um conflito fratricida entre o exército republicano, socialista e internacionalista e as tropas do Exército nacionalista, que adquiriu dimensão internacional com a participação de milícias alemãs, italianas e da Brigada Internacional comunista. Nos campos de batalha, ele passa por um processo de aprendizagem sobre o valor da vida, da religião, da família, dos amigos e da pátria, e retorna para assumir uma vida burguesa que antes desprezara.

Palavras-chave: Erico Verissimo; Guerra Civil Espanhola; Aprendizagem

Abstract: Based on true account, narrated by two participants in the Spanish Civil War (19361939), Erico Verissimo wrote the novel Saga (1940) about the ficitional course followed by the Brazilian volunteer Vasco Bruno. Without any great purposes in life, that young man, having become bored, participates in a fratricide conflict between the socialist and internationalist republican army and the nationalist army troops, which had an international dimension with the participation of German and Italian troops and the International Communist Brigade. In the battle fields, he undergoes a process of learning about the value of life, religion, family, friends and one's homeland, and returns to assume a bourgeois living he used once to despise.
\end{abstract}

Keywords: Erico Verissimo; Spanish Civil War; Learning

\section{Introdução}

Membro voluntário da Brigada Garibaldi, o brasileiro Vasco Bruno, protagonista-narrador de Saga (1940), de Erico Verissimo, encontra-se em Tortosa, uma cidade espanhola destruída pela guerra civil, e se lembra de uma experiência que tivera aos doze anos, enquanto lia o romance $A$ volta ao mundo em oitenta dias, de Júlio Verne. Com planos de uma viagem futura, ele apontou, de olhos vendados, para o mapa mundi e, assinalou ao acaso uma cidade na Espanha, Tortosa. A visita a essa urbes seria seu projeto de vida no além-mar, na Península Ibérica, na região de seus ancestrais.

A realidade sangrenta, entretanto, o chama à razão: a Tortosa imaginada era diametralmente oposta à Tortosa vivenciada, dividida entre os exércitos rivais de espanhóis contra espanhóis, numa luta encarniçada entre o governo legalista e socialista e os golpistas nacionalistas, comandados pelo general Franco. Abalado pela crueldade dos combates, o amargurado Vasco reflete sobre os incríveis acasos da vida e a transformação de um sonho em pesadelo horrendo, bem como sobre a sua trajetória de rapaz ocioso, sem grandes perspectivas de vida, que, de forma impetuosa, embarca para prestar sua solidariedade aos oprimidos civis em uma guerra do outro lado do oceano.

Baseado no diário do brasileiro Homero de Castro Jobim e nos depoimentos do espanhol Jesus Corona, Erico Verissimo publica, no ano de 1940, o romance Saga, em uma época de alinhamento do Estado Novo (1937-1945), o governo ditatorial de Getúlio Vargas, com as potências alemãs e italianas.

Em Saga, Verissimo apresenta distintas concepções do heróico conceito de saga: A realidade nua e crua da Guerra Civil Espanhola (1936-1939), por meio da vida do desenhista Vasco, um rebelde sem causa, que 
por se sentir aprisionado no "círculo de giz" social, se catapulta em uma aventura tresloucada, como soldado inexperiente na Brigada Internacional, organizada por Stalin, em um apelo internacional, a partir de Paris.

Sua participação desesperada nas aniquiladoras etapas finais da guerra (1938 e 1939), com outros internacionalistas (o chileno Garcia, o sueco Axel, o italiano Vergara, os estado-unidenses Brown e Green, entre outros anônimos), - no avanço vitorioso do exército franquista na frente do rio Ebro, na tomada da Catalunha e no êxodo dos fugitivos para a França - serão analisadas a partir de seu projeto pessoal de "utopia libertária", seus "sonhos diurnos", e seu "otimismo militante" ("filosofia da esperança”, de Ernst Bloch).

\section{A Guerra Civil Espanhola (1936-1939) e a postura dos intelectuais}

A Frente Popular, desde 1934 no poder parlamentarista da Espanha, sob a presidência de Manuel Azaña e do Primeiro-Ministro Largo Caballero, sucedido posteriormente por Juan Negrin, toma medidas impopulares de cunho socialista: apoio total aos operários em inúmeras greves; autonomia da Catalunha e do País Basco; postura anticlericalista e contra o poder político e financeiro dos industriais, dos latifundiários, dos empresários e do alto clero. As Forças Armadas conspiravam e o assassinato do deputado monarquista, Calvo Sotelo, em 13 de junho de 1936, provoca o sinal para o golpe de estado. O "poder vermelho" começa a ser derrubado pelo General Franco e pelos seus companheiros - o General Sanjurjo, o General Mola, o General Goded e o General Queipo de Llano -, a partir do dia 17 de julho de 1936, com milícias do Marrocos, protetorado espanhol atlântico.

A Alemanha e a Itália, interessadas nos minérios espanhóis vitais para a indústria de armamentos - volfrâmio, mercúrio, zinco, cobre e ferro -, apoiam os golpistas e enviam técnicos militares, armas, aviões e até mesmo tanques de guerra e submarinos. Por motivos ideológicos, a União Soviética fornece pessoas especializadas, bem como material de artilharia, armamentos e munições e incentiva a formação de uma Brigada Internacional.

A Comissão de Não-Intervenção, reunida no dia 9 de setembro de 1936, em Londres, com representantes de 26 nações, delibera pela neutralidade, em um conflito que já tinha a intervenção de hegemonias capitalistas e uma hegemonia comunista. A Assembleia Geral da Liga das Nações, iniciada no dia 21 de setembro, ignora a Guerra Civil Espanhola, não incluindo tal tema em sua pauta. (ELSTOB, 1978, p. 52-53; 68, 70 e 103; MATTHEWS, s.d., p. 140, 141, 144, 201 e 203; THOMAS, 1964, p. 210)

Nesse ano de 1936, no qual o escritor Federico Garcia Lorca foi assassinado por inimigos da Frente nacional e simpatizantes de Franco, Walter Ulbricht escreve um panfleto, distribuído na Alemanha, com um alerta sobre a dimensão internacional do conflito espanhol: Trata-se de preparativos de uma guerra mundial (ULBRICHT, 1953, p. 125).

Na chamada "guerra entre irmãos", desde julho de 1936 até março de 1939, o exército nacionalista dos Generais enfrentou o exército republicano socialista, que contava com a ajuda dos "internacionalistas, os voluntários da Brigada Internacional. Em 1937, a região norte (País Basco e Astúrias) é conquistada pelo exército franquista. Nos meses de fevereiro a abril de 1938, depois da batalha por Teruel, o exército nacionalista alcança o Mediterrâneo, dividindo a zona republicana. No entanto as forças socialistas tentam, sem sucesso, reunificar o território na batalha de Ebro, ocorrida de julho a novembro do mesmo ano. Em 1939, a Catalunha é tomada pelos nacionalistas em campanha relâmpago, em janeiro e fevereiro e, Madri é conquistada no dia 27 de março. [Essas etapas são mostradas na trajetória do protagonista Vasco Bruno em Saga].

No dia $1^{\mathrm{o}}$ de abril, o Generalíssimo Franco ${ }^{1}$ proclama a vitória dos nacionalistas em uma guerra fratricida que teve um saldo de aproximadamente 1 milhão de vítimas dos exércitos inimigos. (JACKSON, 1976, p. 268; SILVA, 2006, p. A20).

A indignação de escritores e jornalistas diante dos embates sangrentos e da arbitrariedade e omissão de países hegemônicos se torna pública, principalmente, em julho de 1937, em Madri, durante o Segundo Congresso Internacional para a Defesa da Cultura. Os manifestos de Rafael Alberti, Bergamín, Machado e Miguel Hernández, bem como do norte-americano Ernst Hemingway e do francês André Malraux refletem a perplexidade deles a respeito da omissão de nações poderosas indiferentes.

No evento organizado, em 1936, para se pensar o papel da cultura em épocas obscuras e se debater o papel e o poder do intelectual diante de crises, o escritor alemão Bertolt Brecht envia um texto aos congressistas, no qual acusa a utilização pelas ditaduras fascistas de terríveis métodos contra os proletários estrangeiros, já utilizados contra o povo alemão e o italiano. Solidário com o sofrimento do povo espanhol, ele defende o uso de armas concretas para defender a cultura (BRECHT, 1982, p. 72 e 74). No mesmo ano, Graciliano Ramos escreve Terra de Espanha, uma denúncia contra a internacionalização do conflito.

O reflexo estético da Guerra Civil Espanhola em obras artísticas e literárias inicia-se em 1937 com o quadro

\footnotetext{
Nomeado Supremo Comandante das Tropas e Chefe de Estado, em setembro de 1937, o General Franco obtém o reconhecimento do seu governo pela França e Inglaterra e Estados Unidos da América, no ano de 1939 e governa com mão de ferro até 1975
} 
Guernica, de Picasso, e textos a partir do mesmo ano: Wir sind mit euch!, de Friedrich Wolf; e A quinta coluna, de Ernst Hemingway que também escreve Por quem dobram os sinos? e Os fuzis da Senhora Carrar, de Bertolt Brecht. Outras publicações alemãs são: os romances Grüne Oliven und nackte Bergen, de Eduard Claudius, Leutnant Bertrand, de Bodo Uhse, Begegnung am Ebro, de Willi Bredel; as poesias Camaradas, de Erich Weinert, bem como as peças teatrais de Erich Weinert, Ludwig Renn (ADLING, 1965, p. 67-68; e MITTENZWEI, 1982, p. 146). George Orwell chega na Espanha, fica quatro meses (1936) e escreve Homenagem à Catalunha (SILVA, 2006, p. A20).

Brasileiros também manifestam suas reflexões críticas contra a guerra e a omissão de outros países: Carlos Drummond de Andrade nos poemas Notícias de Espanha e A Federico Garcia Lorca; Jorge Amado no romance Agonia da noite (1950) e Guido Guerra no conto Faça-se o desespero ou lembrança que embala a dor (1981) (MEIHY, 1998, p. 230).

No artigo Saga: um testemunho humanista, o pesquisador Flávio Loureiro Chaves interpreta o romance de Verissimo, como o depoimento de um humanista pleno de perplexidades e dúvidas: "no momento em que o humanismo, herança duma cultura liberal e democrática, atravessou a sua pior crise. A literatura apresenta-se então como o território onde as personagens de ficção podem impugnar a realidade, preenchendo a sua insuficiência" (CHAVES, 1997, p. XXIII).

\section{A filosofia da esperança, de Ernst Bloch}

Saga pode ser interpretada sob o prisma da filosofia da esperança, do filósofo alemão Ernst Bloch (1885-1977), que aprofunda a questão da utopia libertária na obra $O$ princípio esperança (1959). Para Bloch a utopia é um topos da atividade humana com uma consciência antecipadora e com sonhos diurnos, no qual existem imagens do desejo [Wunschbilder] e de uma situação que ainda-não-é [Nochnicht-Sein], mas que pode vir-a-ser. Ele apresenta os contornos da possibilidade de um futuro possível, a ser alcançado por meio do engajamento coletivo e solidário das pessoas (otimismo militante). Enquanto que o futuro inautêntico reflete uma esperança trivial e banal, o futuro autêntico tem um excedente que permite a transformação da imaginação utópica em uma realidade humana em forma de um amanhã (utopia concreta e utopia libertária). (BLOCH, 2005, p. 29-48; 79-114; e 193-245).

\section{Euforia, desencanto e nascimento do "homem novo" em Saga}

Antes da publicação de Saga (1940), um romance com espaço internacional, em meio às atribulações bra- sileiras no governo de Getúlio Vargas e aos conflitos bélicos espanhóis, Erico Verissimo havia tematizado a decadência da família Albuquerque, uma aristocracia agrária de Jacarecanga, e a luta de Clarissa, seu primo Vasco e familiares para sobreviverem em Porto Alegre; a vida da classe média e rica; e a ascensão dos imigrantes italianos e alemães, entre outros temas relacionados à história do Rio Grande do Sul nas seguintes obras: Clarissa (1933), Caminhos cruzados (1934), Um lugar ao sol (1936) e Olhai os lírios do campo (1938) (BOSI, 1977, p. 458).

No Prefácio a uma nova edição de Saga, de 1966, Erico Verissimo esclareceu a gênese do romance, que refletiu suas concepções pessoais sobre a paisagem geopolítica européia no final dos anos 1930, cuja intelectualidade, simpatizante ou afiliada ao Partido Comunista Russo, ficou abalada com a assinatura de um Pacto de não-agressão firmado entre Stalin e Hitler, em 23 de agosto de 1939, e a consequente deflagração da Segunda Guerra Mundial:

Saga foi escrito naqueles sombrios meses de 1940, quando as tropas nazistas, com suas brutais Panzerdivisionen, se aproximavam invencivelmente de Paris. Para nós que amávamos a França e detestávamos o nazismo, isso não era apenas o fim da Guerra, mas também o fim do mundo, o fim de tudo. Rússia e Alemanha tinham firmado um pacto de não agressão. No Kremlin, von Ribbentrop e Stalin, cada qual com uma taça de champanha na mão, haviam trocado brindes cordiais. Nas altas esferas governamentais do Brasil viam-se figurões civis e militares que não escondiam sua simpatia pelo hitlerismo, seu fascínio pelos feitos da Wehrmacht. Tudo nos levava a crer que o destino próximo de todos os liberais seria o internamento num campo de concentração - caso em que não nos importaria a cor da camisa daqueles que nos levassem para lá. (VERISSIMO, Prefácio, 1977, p. XI)

Elcio Loureiro Cornelsen, no artigo A trajetória de um gaúcho na Guerra Civil Espanhola, destaca o legado do romance de Erico Verissimo: "a relevância de Saga situa-se naquilo que possui de particular: sua gestação como processo resultante da relação entre Literatura e História num período conturbado: o Estado Novo (19371945), regime ditatorial sob o governo de Getúlio Vargas". (CHAVES, 2009, p. 248).

O romance narrado em $1^{1}$ a pessoa, de caráter testemunhal ${ }^{2}$, que apresenta a trajetória de um jovem

\footnotetext{
2 Verissimo teve acesso ao diário de Homero de Castro Jobim, ex-brigadista do Rio Grande do Sul, que participou da Guerra Civil Espanhola, e aos depoimentos de Jesus Corona, um espanhol que vivia no Rio Grande do Sul, e que o informou sobre o campo de concentração de Argèlessur-Mer, onde foram confinados os refugiados da Espanha na França após a derrota bélica do Governo republicano socialista. Erico Verissimo dedicou Saga a Homero de Castro Jobim e a Jesus Corona (VERISSIMO, Prefácio, 1977, p. IX).
} 
gaúcho, o descontente Vasco Bruno, que vivia à procura de si mesmo, está dividido em quatro partes: $O$ círculo de giz, Sórdido interlúdio (Espanha e França), O destino bate à porta e Pastoral (Brasil). Na primeira parte -O círculo de giz - é abordada a etapa final da guerra civil no cerco à Catalunha: a chegada de Vasco e dos últimos voluntários para o exército republicano em Cerbère, na França; a partida para Portbou, na Espanha; o treinamento militar em Figueiras, centro da Brigada Internacional e em Besalu (Gerona); a viagem para ofront - Ollot, Barcelona, Tarragona, Cambrills até Rasquera, perto do rio Ebro-; o embate em Tortosa e na Serra de Caballs- e a participação de Vasco e de outros na organização de fugitivos de Figueiras rumo à França ${ }^{3}$. Em Sórdido interlúdio é narrada a terrível marcha deles rumo à França, depois da desmobilização dos voluntários internacionalistas, e a fuga de espanhóis, em suas várias facetas do individualista cotidiano no campo de concentração de Argelès-sur-Mer, nos Pirineus Orientais ${ }^{4}$.

\footnotetext{
3 Na primeira parte, O círculo de giz, Vasco Bruno chega, em março de 1938, em Cérbere na França, conhece o chileno Carlos Garcia e o sueco Axel e cerca de 200 eufóricos membros da Brigada Internacional, os internacionalistas. Partem no trem de Perpignan, chegam a Portbou, uma cidade espanhola destruída por aviões e pelo tifo, seguem com o norte-americano Samuel Brown para Figueiras, para o "Cuartel de las Brigadas Internacionales" e depois para Besalu, a fim de receberem treinamento militar com a Brigada Garibaldi. Conhecem o ilusionista Marcântonio De Nicola e o palhaço, malabarista e equilibrista, Pepino Verga, que é fuzilado após ter violentado uma menina. Continuam a viagem para Ollot, por Barcelona, Tarragona até Cambrills, local do Quartel General do Comando da 45. Divisão com três Brigadas Internacionais, que também têm membros espanhóis, e conhecem Paul Green, o milionário norte-americano. Como tropa de reserva partem de caminhão para Rasquera, localizada a $5 \mathrm{~km}$ da margem esquerda do rio Ebro, onde conhecem a dura realidade: desorganização militar, sujeira e carência de armamentos e de comida. Transferidos para as trincheiras de Miravet, presenciam o horror noturno de bombardeios aéreos, de tiros de canhões, que levam ao desespero e a morte. O aprisionamento de soldados inimigos, espanhóis, a morte de Axel com as pernas decepadas e as notícias do ataque aéreo à Barcelona, provocam em Vasco o desejo de deserdar. Ao ser transportado, ferido na perna, conhece a amorosa Joana, em uma estação de trem, que o segue até Barcelona. No retorno à Serra de Caballs, o convalescente não encontra mais De Nicola, morto por ferimento no peito, e Paul Green, fuzilado por tentar deserdar com compatriotas. Sebastian Brown cai crivado de estilhaços de granadas e Vasco com terríveis ferimentos no pulmão na perna é operado, no hospital de Mataró, pelo canadense, Dr. Andrew Martin. No final da guerra, Vasco participa, em Figueiras e em Barcelona de um batalhão de recuperação de material de guerra abandonado pelas forças e de assistência às populações civis fugitivas, rumo à França, pelas estradas repletas de neve, ameaçadas por criminosos saqueadores e por tanques italianos.

4 Na segunda parte de Saga, Sórdido interlúdio, é apresentado o desumano cotidiano no campo de concentração de Argelès-sur-mer, nos Pireneus Orientais, onde ficam somente os homens, que inspecionados por tropas senegalesas, dormem no relento em uma "espécie de fétida cooperativa de calor". (VERISSIMO, 1976, p. 161). No desespero e desamparo, saqueam caminhões e carros vindos da Espanha, e tiram pranchas de madeira, depósitos de gasolina, estofos de banco, holofotes, pneus e placas de metal para construção de abrigos e improvisação de utensílios de cozinha. O acampamento símbolo do fim das esperanças da vitória comunista do governo da Frente Popular e do início da ditadura militar de Franco está repleto de pessoas desesperadas e aniquiladas pela água salobra, escassa e suja; comida racionada e estragada; disenteria; vermes e lombriga; desordem e indisciplina; brigas com assassinato pessoas com acessos de loucura. Nesse inferno concreto, Vasco, atacado pela colite, constata que não há solidariedade e sim o individualismo humano e, desencantado e com saudade do Brasil escreve uma carta ao embaixador brasileiro, em Paris, e pede o seu retorno.
}

Em Saga, a questão da "utopia libertária" (Ernst Bloch) abrange duas facetas totalmente opostas, pois o conflito histórico com intervenção internacional reflete modelos hegemônicos em oposição: o interesse de Moscou em apoiar o governo socialista espanhol e o objetivo da Itália, da Alemanha, da França e da Inglaterra em combater o "perigo vermelho". Diante desse confronto ideológico, os soldados de Franco acreditam e lutam pela libertação da Espanha das garras comunistas; e, de outro lado, a milícia socialista e a Brigada Internacional sonham com a implantação de uma república comunista, igualitária e solidária.

A presença da Brigada Internacional, de armas e de aviões russos, aviões italianos Sávio-Marchetti e de aviões alemães modelo Heinkel e Junkers, citados no romance, refletem a participação de pessoas e equipamentos estrangeiros no conflito espanhol, situação repudiada pelo espanhol Dom Alfonso e mostrada a Vasco, o qual narra ao velho senhor que: "[...] continua a me tratar com uma hostilidade positivamente cômica. Parece ter ciúmes desta guerra que, segundo ele, deve ser feita "entre nosotros los españoles", sem a interferência de estrangeiros". (VERISSIMO, 1976, p. 121).

\subsection{A solidariedade comunista da Brigada Internacional e a crua realidade}

A eclosão da Guerra Civil Espanhola (1936), um conflito entre socialismo e capitalismo, entre o governo da Frente Popular e o exército do General Franco, teve uma grande visibilidade mundial, principalmente, pela publicação de fotos dos massacres de crianças e de mulheres. Tais fatos motivam jovens, como o brasileiro Vasco Bruno, o estado-unidense Samuel Brown e o sueco Axel, entre outros, a lutarem pelo final da guerra, como forma de uma atitude humanista, sem convicção política. Outros internacionalistas, como De Nicola e Cantalupo, participam motivados por profundas reflexões ideológicas.

O início da saga pessoal de Vasco, que o levou a demonstrar solidariedade internacional ao exército dos nacionalistas republicanos nos campos de batalha, deveu-se à sua leitura de notícias sobre os massacres da população civil na Espanha. Desenhista impetuoso sem grandes projetos, ao encontrar, em um Café, em Porto Alegre, um jornal, acredita ter encontrado uma razão de viver. Ele viaja, alista-se na Brigada Internacional comunista para ir socorrer pessoas em perigo, como incentivo ao seu tédio particular.

Sem postura ideológica, Vasco compra uma passagem de terceira classe e, em março de 1938, desembarca em Cérbere, na França, totalmente, despreparado, como muitos outros. Já no início da reunião dos internacionalistas, Vasco se incomoda com o odor dos 
companheiros no trem ("uma festa 'internacional' para o olfato") e escuta a irônica observação de Garcia: "- Se você pensa que na Brigada Internacional os legionários cheiram a Coty ou Caron, é melhor ir desde já perdendo a ilusão" (VERISSIMO, 1976, p. 8).

As esperanças ideológicas marxistas estão presentes já na recepção dos voluntários, na França, na fala eufórica do capitão Rodrigues que: "Anima-os com palavras de entusiasmo em torno da nobre missão dos "internacionales", fala-lhes em vitória e no advento de um mundo melhor" (VERISSIMO, 1976, p. 3 e 4). O clima de alegria imensa e de "otimismo militante", à beira da histeria, reflete-se no trem de Perpignan, que parte com cerca de 200 voluntários eufóricos, os quais cantam entusiasmados; alguns entoam Bandiera Rossa e Marselhesa. A recepção calorosa do Comissário Cantalupo que tem um estilo peculiar e oratório de persuasão, reflete os "sonhos diurnos", os ideais plenos de esperança na vitória socialista:

Compõe-se duma combinação de doçura evangélica, pombas líricas, imagens místicas, com visões apocalípticas e blasfêmias italianas. Às vezes, do auge do entusiasmo ele cai num terreno grosseiramente cômico para não raro entrar inopinadamente no domínio da mais desbragada pornografia. Os homens rompem então em gargalhadas e desse modo são mantidos com a atenção em suspenso. Mas lá de novo está o Comissário Cantalupo sereno e profético, a pintar no quadro do futuro o mais justo e belo dos mundos. (VERISSIMO, 1976, p. 45 e 46).

A chegada retumbante de 200 estrangeiros, alguns entoando hinos como Bandiera Rossa em Portbou, uma cidade espanhola já destruída pelos bombardeios aéreos, provocou o brado desesperado de uma das fugitivas de Irun e San Sebastian: “- Ustedes estan locos, locos, locos!" (VERISSIMO, 1976, p. 6), que não podia entender o ânimo dos combatentes que pareciam excursionistas rumo a uma colônia de férias no verão.

Observador atento, Vasco constata que está com voluntários que ali estão engajados por motivos políticos e extra-políticos, em um "estranho museu vivo ou num supermercado de almas", "os idealistas puros" como Axel, Paul Green e Samuel Brown; alguns "tipos fabricados em série, criaturas que oferecem apenas um interesse de superfície"; os que vêem na guerra "seu jogo predileto", "uma forma de suicídio" ou a fuga para um "drama íntimo" e, aqueles que têm "obsessão pelo heroísmo" ou buscam "o heroísmo teatral e ruidoso e exibicionista" ou emoções violentas. Para De Nicola, alguns formam uma "corja de burgueses inúteis" e, para Brown são "homens brincando de guerra" (VERISSIMO, 1976, p. 38; 40 e 41; 61). Para os combatentes, entretanto, eles estão participando de uma luta coletiva e solidária por uma vida melhor, mesmo arriscando a própria vida.

Os participantes marxistas dividem-se entre aqueles "[...] raros, os estranhos, os misteriosos, os que não vivem de acordo com uma rígida fórmula doutrinária", e os que têm ortodoxa "consciência partidária"; outros têm com "ódio dirigido" e "boa dose de espírito messiânico". O brasileiro constata que alguns são "Fugitivos de países onde o fascismo impera, vieram para derrubar um regime capitalista"; outros "Parecem achar como Lenine que esta não é a hora de afagar cabeças mas sim de rachar crânios". Parte deles se dirige a Vasco e "Falam-me da situação na Europa e do mundo e só sabem apreciá-la em termos de marxismo" (VERISSIMO, 1976, p. 41). Um é da Legião Estrangeira, outros são ex-combatentes da Primeira Guerra Mundial e alguns poucos são fugitivos do nazismo.

Os direitos e deveres dos integrantes da Brigada Internacional são muitos: a contribuição obrigatória do modesto soldo de 300 pesetas para a lista de donativos e prol das crianças espanholas e para os auxílios de retaguarda, bem como a exibição permanente de ânimo durante o exaustivo treinamento e nos enfrentamentos bélicos. As punições são severas com pena de morte para estupro, como no caso posterior de Pepino, e para deserção que custou a vida do ingênuo Paul. Caso haja fraquezas, os soldados são enquadrados no batalhão disciplinar formado por insubordinados, derrotistas, saqueadores: "[...] homens tristes, esfarrapados, cadavEricos cuja missão é cavar trincheiras na linha de fogo, abrir estradas e enterrar cadáveres. Andam em sua maioria descalços e dão a impressão de galés. Recebem uma ração reduzida de alimento e não têm direito a pão, vinho e cigarros. Trabalham às vezes de sete a oito horas a fio, sob a chuva ou sob o sol. É a unidade do terror e os seus soldados já nem mais parecem homens" (VERISSIMO, 1976, p. 102).

A morte do amigo Axel, um golpe terrível em seus "sonhos diurnos" leva Vasco ao desespero e, por isso, é consolado por De Nicola: “- Não é nada. Que outra coisa vai a gente esperar da guerra/ Flores? Valsas? Vamos, vamos. Venha tomar um pouco de ar". A perda trágica do amigo e as notícias do ataque aéreo à Barcelona provocam nele o desejo de deserção, mas acaba ficando, incentivado por De Nicola que o aconselha a fazer "sua reeducação sentimental diante do perigo" (VERISSIMO, 1976, p. 93 e 97).

Imagens de heroísmo épico e utópico, geralmente citado em obras artísticas, literárias e cinematográficas sobre a guerra, são poucas: uma é a do pretenso proclamado pelo chileno Garcia, fã incondicional de D. Quixote, dado às bravatas antes das batalhas, que o cita: "Yo soy aquel para quien están guardados los peligros, lãs grandes hazañas, los valerosos hechos" (VERISSIMO, 1976, p.81). 
Um episódio "heróico" e solidário cristalizou-se na ida de Vasco e De Nicola para pegar verduras perto do rio e do exército inimigo, sob risco de vida.

O heroísmo consciente em prol de uma causa é demonstrado por Cantalupo:

Incitava-nos com palavras. Uma bala atravessoulhe $\mathrm{o}$ antebraço, que começou a sangrar. O comissário continuou a andar. Cantava com toda a força dos pulmões. Um tiro no peito fê-lo calar-se. Mas ele prosseguiu no avanço, sangrando, lançando blasfêmias, morrendo aos poucos. Enterramo-lo nas proximidades do castelo de Miravet. (VERISSIMO, 1976, p. 98)

Um jovem toscano de 18 anos, no meio de homens barbudos, tem uma "bravura admirável" e parece uma criança no meio de adultos: "Dir-se-ia estar brincando de guerra. É um idealista e acredita em que não tardará o advento de um mundo melhor" (VERISSIMO, 1976, p. 99).

Em contato com o cotidiano regrado e disciplinado do treinamento militar, os soldados percebem que o sonho libertário exige muito esforço e determinação. A dura vida em comunidade militar tem também momentos de ternura e solidariedade entre eles, como na brincadeira feita por Pepino para o negro Brown: com pedaço de carvão o italiano desenhou na laje seu plano político em um mapamundi, com figuras e destaque para a Itália, a Espanha e a Abissínia, invadida pelo governo italiano: "A coisa é simplíssima. Vencemos Franco, derrubamos Mussolini do poder e coroamos Brown imperador da Abissínia" (VERISSIMO, 1976, p. 33).

Em conversa com o espanhol Dom Afonso, Vasco é confrontado com uma verdade: A máquina de interesses financeiros prevalece na engrenagem dos conflitos bélicos e ele deveria preocupar-se com a situação do Brasil, governado pela ditadura Vargas:

E um jovem idealista atravessa o Atlântico, metese na Espanha, alista-se na Brigada Internacional e de carabina em punho sai a dar tiros, a matar e a correr o perigo de ser morto, convencido de que está vingando o massacre dos inocentes ... Seria melhor que tivesse ficado na sua pátria tratando de evitar com todos as suas forças que ela seja vítima da mesma traição que feriu a Espanha. (VERISSIMO, 1976, p. 124 e 125)

No campo de concentração francês, etapa final da guerra perdida dos socialistas, uma ideologia que motivou a participação de tantos espanhóis e estrangeiros, em uma guerra de maquinaria moderníssima, prevalece o modelo capitalista, em detrimento do modelo comunista de igualdade social, pois as negociatas e as jogatinas se instalaram, em função do lucro de alguns, causando dívidas e até mesmo um assassinato: "Entre nós já havia capitalistas e proletários: dum lado, homens que sabiam fazer negócio e tinham senso econômico; e de outro, criaturas que mesmo nesta situação de penúria niveladora 'descobriram' um meio de ficar ainda abaixo do nível geral” (VERISSIMO, 1976, p. 168).

O "princípio esperança" (Bloch) cristaliza-se nas expectativas para os sobreviventes da guerra. $\mathrm{O}$ desejo por dias melhores desabrocha no coração do jovem soldado catalão, que perdeu uma perna na guerra, mas dança rumba no hospital em Barcelona, da mesma forma fortalece a moça, que ganhou leite condensado de Vasco para seus filhos pequenos, para não esmorecer, acreditando que um dia seu marido, desaparecido na frente do Ebro, irá regressar (VERISSIMO, 1976, p. 152 e 156).

$\mathrm{Na}$ dantesca atmosfera do campo de concentração francês brilha uma luz de esperança com a reunião de homens sensatos e equilibrados que assumem uma liderança positiva para a melhoria de vida dos refugiados:

E no meio desta população, ignóbil de vermes, deste nó imenso de lombrigas - começaram a surgir homens, personalidades, criaturas que se destacam da massa, que revelam ânimo forte, espírito organizador. São vozes lúcidas e cheias de esperança no meio da desordem. (VERISSIMO, 1976, p. 164).

\subsection{O processo de aprendizagem de Vasco}

A saga do brasileiro Vasco Bruno na Guerra Civil Espanhola faz com que ele se transforme de jovem ocioso, "rebelde sem causa" e sem grandes projetos em um "homem novo", ou seja, a "utopia libertária" (Bloch) tem de ser vivida em seu próprio país, governado pela ditadura Vargas, com os brasileiros e em sua própria família.

Durante os terríveis acontecimentos nas trincheiras e cassamatas e o contato com corpos de companheiros em decomposição, Vasco, o entediado jovem que por impulso saiu de Porto Alegre para lutar na guerra, encontra uma razão de sobreviver no meio da sordidez humana: "Dentro de mim existe ainda uma luz de esperança. A beleza e a paz ainda não desapareceram do mundo. É preciso ter coragem para - não apenas ter coragem de lutar contra a morte, mas a lenta, paciente e obscura coragem de esperar, resistindo à desagregação moral (VERISSIMO, 1976, p. 135).

Abalado com o alojamento militar no mosteiro, Vasco tem esperança que: "Estas cantigas vão passar como passar também vão as frases e exclamações de ódios que os guerreiros de hoje escrevem com giz ou pixe por cima das vestutas legendas latinas" (VERISSIMO, 1976, p. 48). O brasileiro, que demonstrou uma arrogância sem limites ao comandante, respondendo "Escute [...] eu 
não sou nenhuma repartição ambulante de estatística". (VERISSIMO, 1976, p. 46), ao ser interrogado por fatos sobre o Brasil, começou uma lenta transformação: "Vou conquistando palmo a palmo, com pesadas perdas, territórios interiores que ainda não domino. Quando esta guerra terminar haverá na terra pelo menos um homem novo" (VERISSIMO, 1976, p. 97 e 98).

Acostumado a chocar familiares e amigos pelas suas atitudes incomuns, principalmente àquelas relacionados à igreja, Vasco tem uma revelação íntima surpreendente durante sua estada na Espanha. Nos mosteiros de Figueiras e Besalu, confiscados como alojamentos e transformados em ambiente para militares, o brasileiro se abala com as dessacralizações ocorridas e descobre suas raízes brasileiras e sua identidade cristã:

Tenho na alma vários séculos de cristianismo. Mais de uma vez quando adolescente proclamei aos quatro ventos, com ar impávido, a minha heresia. Mas uma igreja, sempre me impõe silêncio. É como de repente sobre a superfície esfuziante da minha arrogância caísse um véu opaco. (VERISSIMO, 1976, p. 53).

Suas reflexões iniciais sobre Deus, trocadas com Brown, que lhe falava do "ouro da fé" e, sobre o bem e o mal e a eternidade com o médico Martin, levam ao seu fortalecimento espiritual. Outros entendimentos sobre a alegria na vida, a solidariedade e a esperança em dias melhores são apresentadas também em várias etapas de sua trajetória na Espanha: em sua chegada na França, durante o desenrolar da batalha na Catalunha e no retorno à França, como um ciclo fechado depois de expectativas, desencantos e esperanças, que se reinicia no Brasil.

Vasco descreve seu conflito ao tentar romper as amarras de sua vida que para ele significavam o casamento com Clarissa e uma vida medíocre. O "salto do círculo de giz", suas reflexões sobre a condição humana, no redemoinho da amarga experiência em uma guerra civil, o levam à seguinte conclusão:

Atravessei o oceano para vir ao encontro justamente das coisas que mais odeio. Não posso culpar ninguém do que me aconteceu. Quando eu vivia no Brasil a minha vida de sonhos insatisfeitos, comparava-me ao peru que, segundo se diz, metido no centro dum círculo traçado a giz no chão, se julga irremediavelmente prisioneiro dele. Um dia achei que devia correr para a liberdade, saltando o risco de giz. Cortei as amarras que me prendiam a todas as convenções sociais e a esse manso comodismo dos hábitos. Dei o salto... E agora, moendo e remoendo experiências recentes, comparando-as com as antigas, chego à conclusão de que a vida não passa duma série numerosa de círculos concêntricos. A gente salta por cima de um apenas para verificar depois que está prisioneiro de outro e assim por diante. É a condição humana. (VERISSIMO, 1976, p. 147)
O "homem novo", o internacionalista Vasco, aprende que não adianta fugir de seus próprios problemas para viver o de outros na Espanha. Ao retornar a Porto Alegre depois da sobrevivência física e psicológica no front militar e no campo de concentração, Vasco confessa a si mesmo ao abraçar sua namorada Clarissa:

Creio que sou um homem novo. No subsolo de meu ser em que cada provação vale por muitos anos, havia um pedaço de carvão bruto e negro que, trabalhado de sofrimentos, se cristalizou num pequeno diamante. Custou a vida de muitos homens, de muitas ilusões e esperanças: agora ele cintila puro e límpido e eu quero dá-lo de presente ao único coração que neste vasto mundo vário parece ainda pulsar por mim [...] Um pobre peru ébrio que volta voluntariamente para o seu círculo de giz. (VERISSIMO, 1976, p. 174 e 176)

Grato por ter sobrevivido a guerra e por ter aprendido a valorizar sua pátria, seus parentes e seus amigos, Vasco reflete: "Axel... Brown... Green... Martin... De Nicola... Juana... Dom Miguel... Alfonsito. Seja como for, esta guerra para mim não foi de todo perdida, porque eu vos conheci” (VERISSIMO, 1976, p. 157).

\section{Conclusão}

Erico Verissimo antecipou nessa narrativa sobre a Guerra Civil Espanhola (1936-1939), os horrores da Segunda Guerra Mundial. O romance (1940) é uma resposta artística (Ernst Bloch) do escritor brasileiro ao conflito, que reflete o crítico papel do intelectual diante de uma guerra entre espanhóis, apoiada militarmente pela Itália, Alemanha e União Soviética e ignorada pela França e Inglaterra.

VERISSIMO discute em Saga a "utopia libertária”, a participação de tantos estrangeiros, alguns que arcaram com os custos financeiros para chegar até ali, e que foram motivados, sobretudo, pela emoção, pelos "sonhos diurnos" e pelo "otimismo militante" (Bloch), pois parece que a guerra seria pasteurizada, inodora e indolor:

É esquisito como, ao pensar na guerra, a gente nunca se lembra desses pormenores sórdidos ou então simplesmente triviais. Tem-se em vista a ação, a luta, o ímpeto, as arremetidas corajosas ou então a silenciosa e subterrânea luta contra o medo. Poetas e jornalistas, romancistas e historiadores, antes de fixar a guerra em livros, revistas e jornais passam-na por uma peneira cuja trama é feita de idealismo, romances, e clarinadas gloriosas. (VERISSIMO, 1976, p. 71)

A biografia de Vasco Bruno serve como base para o escritor criticar a radiografia econômica e sociopolítica da Guerra Civil Espanhola: um conflito perifErico 
apoiado por superpotências interessadas em matériaprima, de um lado; e infiltrado por disputas ideológicas capitalistas e comunistas, de outro. Como intelectual engajado, Verissimo desmistifica o mecanismo da guerra e a engrenagem econômica dos bastidores da indústria bélica que provoca a morte de milhões de pessoas. Desvenda ainda, o continuísmo "colonial" europeu: a presença de contingente colonial francês como vigilantes - soldados "mouros" do Marrocos, protetorado espanhol; e de soldados senegaleses - e de carne congelada de Madagascar, isto é, "pessoas e produto coloniais" no campo de concentração de fugitivos da guerra, na França.

Em um doloroso processo de aprendizagem - de alienado rebelde a coveiro de corpos de companheiros em decomposição - Vasco reencontra sua identidade brasileira, ainda que edulcorada, reafirma sua raízes cristãs e de um estado de rebeldia, de euforia, de desencanto e de desespero se apazigua com si próprio e se revitaliza, pleno de esperança, para recomeçar sua vida no Brasil, em um "futuro autêntico", como um "homem novo" (Bloch). Suas memórias devem servir de reflexão para outros.

Com o sentimento latente de encarceramento social no "círculo de giz" da sociedade burguesa, Vasco aprende na guerra que: "A gente salta por cima de um apenas para verificar depois que está prisioneiro de outro e assim por diante. É a condição humana"(VERISSIMO, 1976, p. 147). Regressado, ele entra no esquema antes rejeitado, casa-se com Clarissa e aguardam a chegada de uma criança (Parte 3 - $O$ destino bate à sua porta, e 4 - Pastoral).

O conceito de saga, ligado a feitos grandiosos e heróis épicos, é desnudado, pois o autor apresenta uma anti-saga por excelência: a saga da guerra verdadeira, sangrenta e aniquiladora de pessoas e da natureza, isto é, a saga do homem comum em sua essência: expectativas, anseios, medo, insegurança, fragilidade, crueldade, pessimismo, solidariedade e esperança. O sueco Axel explica a Vasco: "Na escola em Estocolmo nos contavam muitas sagas... Belas lendas de heróis, conquistadores, príncipes perfeitos e homens do mar [...] Mas como em todas as outras escolas do mundo eles se esqueceram de nos preparar para a vida, a mais estranha das sagas." (VERISSIMO, 1976, p. 60).

A guerra é apresentada em imagens simbólicas e apocalípticas da natureza, das pessoas e até da arte, como o "Cristo Legionário, um Cristo com capacete de aço, uma carabina e expressão de ódio" (VERISSIMO, 1976, p. 51), como representações de um mundo em desagregação no conflito dessacralizador de espaços e de elementos religiosos.

Verissimo critica tanto pesquisadores e escritores, que apresentam uma guerra sem sangue, sem dor e com heróis titânicos, quanto a educação moral e cívica ensinada nas escolas: a glorificação e a legitimação da guerra presente em livros de história e didáticos, hinos patrióticos e até mesmo em brincadeiras. Vasco recordase de um episódio da infância aos 8 anos, quando se divertia com os vizinhos:

As crianças amam a guerra. Não admira. Tudo as leva a isso. As lições de História. Biografias de heróis. $\mathrm{O}$ tamborzinho inglês que não sabia tocar retirada. Napoleão, Leônidas, nas Termópilas [...] O tamborzinho inglês. Marcílio Dias. Nós somos da pátria a guarda. (VERISSIMO, 1976, p. 34)

O brasileiro Erico Verissimo, que utilizou fontes verídicas sobre a participação de brasileiros na Guerra Civil Espanhola e, baseado nelas, mostra cenas sangrentas e, em contraposição ao desespero e desconsolo, apresenta também a alegria de viver e a esperança inquebrantável em meio à perdição da guerra. A postura positiva de vida e o "otimismo militante" são demonstrados por um catalão de 80 anos, que perdeu na guerra filhos, netos, a velha casa, os trigais e as vinhas e que apesar disso, fala com Vasco e com outros soldados e, os encoraja por meio de relatos de seus "sonhos diurnos" (Bloch):

[...] de suas esperanças na ressurreição de sua Catalunha invencível [...] Abana as mãos impressionantes num frenesi e grita para nós as suas palavras de fé, como se quisesse meter à força na alma a sua confiança:

- Todos estes bárbaros passarão, mas a terra há de ficar depois da invasão dos mouros e daquele "perro de Napoleón".

Cala-se um instante e depois, com ar reflexivo, acrescenta:

- A terra é boa, os homens é que são maus. (VERISSIMO, 1976, p. 108).

São imagens da terra redentora e fértil, que com seu ciclo natural revigorante, transmite uma mensagem de alegria na vida e esperança por dias melhores.

\section{Referências}

ADLING, Wilfried. Nachwort. In: BRECHT, Bertolt. Die Gewehre der Frau Carrar. Mitarbeit von M. Steffin. Anmerkungen von Ruth Berlau. Leipzig: Verlag Philipp Reclam, 1965. 77 p. p.63-76.

BLOCH, Ernst. O princípio esperança. Tradução de Nélio Schneider. Rio de Janeiro: Contraponto; EDUERJ, 2005. v. 1.

BOSI, Alfredo. História concisa da literatura brasileira. 2. ed., 7. imp. São Paulo: Cultrix, 1977.

BRECHT, Bertolt. Rede zum II. Internationalen Schriftstellerkongress zur Verteidigung de Kultur. In: BOHNEN, Klaus (Org.). Brechts Gewehre der Frau Carrar. Frankfurt am Main: Suhrkamp, 1982. S. 72-74. 
CHAVES, Flávio L. Saga: um testemunho humanista. In: VERISSIMO, Erico. Saga: romance. Ensaio introdutório de Flávio Loureiro Chaves. 8. ed. Porto Alegre: Globo, 1976. p.XVII-XXIII.

CORNELSEN, Elcio Loureiro. A trajetória de um gaúcho na Guerra Civil Espanhola. Aletria, n. 2, v. 19, p. 247-269, jan.jun. 2009.

ELSTOB, Peter. A Legião Condor e a guerra da Espanha. Tradução de Edmond Jorge. Rio de Janeiro: Renes, 1978. (História ilustrada do século da violência; 3 ).

JACKSON, Gabriel. A república espanhola e a guerra civil 1931-1939. Tradução de Luís A. Pereira. Lisboa: Publicações Europa-América, 1973. v. 1

KESTING, Marianne. Brecht: Mit Selbstzeugnissen und Bilddokumenten. 39. Aufl. Hamburg: Rowohlt, 1999. Mit Namenregister.

MATTHEWS, Herbert L. Metade da Espanha morreu: uma reavaliação da Guerra Civil Espanhola. Tradução de Fernando de C. Ferro. Rio de Janeiro: Civilização Brasileira, s.d.

MEIHY, José Carlos S. B. A literatura como história: revolução e circunstância, a produção intelectual brasileira e a guerra civil espanhola. In: IANNONE, Carlos Alberto et al. (Org.). Sobre as naus da iniciação: estudos portugueses de literatura e história. São Paulo: Fundação da Editora da UNESP, 1998. p. 219-232. (Prismas)

MITTENZWEI, Werner. Die Gewehre de Frau Carrar. In: BOHNEN, Klaus (Org.): Brechts Gewehre der Frau Carrar. Frankfurt am Main: Suhrkamp, 1982. S. 144-166.

SILVA, Beatriz C. O Estado de S. Paulo, São Paulo, 16 jul. 2006. Internacional, p. A20.

THOMAS, Hugh. A Guerra Civil Espanha. Tradução de James Amado e Hélio Pólvora. Rio de Janeiro: Civilização Brasileira, 1964. (Coleção Documentos de história contemporânea; 5-A).

ULBRICHT, Walter. Zur Geschichte der deutschen Arbeiterbewegung, Berlim, 1953. v. 2.

VERISSIMO, Erico. Prefácio (1966). In: VERISSIMO, Erico. Saga. 21. ed. Rio de Janeiro: Globo, 1997. p. XI-XIV.

VERISSIMO, Erico. Saga: romance. Ensaio introdutório de Flávio Loureiro Chaves. 8. ed. Porto Alegre: Globo, 1976.

Recebido: 31 de outubro de 2013 Aprovado: 10 de janeiro de 2014 Contato: denise@unilab.edu.br 